\title{
Food habits of puma (Puma concolor) in the Andean areas of Tamá National Natural Park and its buffer zone, Colombia
}

\author{
Raquel Pacheco Jaimes ${ }^{1}$, Carlos H. Cáceres-Martínez ${ }^{2 *}$, Aldemar A. Acevedo ${ }^{1,3}$, Andrés Arias-Alzate ${ }^{4}$, and José F. González-Maya 5 \\ ${ }^{1}$ Universidad de Pamplona, Grupo de Investigación en Ecología y Biogeografía, Km 1, Vía a Bucaramanga, Barrio El Buque, Edificio \\ Camilo Daza, 543050. Pamplona, Colombia. Email: rackell.900817@gmail.com (RPJ). \\ ${ }^{2}$ Grupo de Investigación en Ecología y Conservación de Fauna Silvestre. Facultad de Ciencias Agrarias, Universidad Nacional de \\ Colombia. Medellín, Colombia. Email: ccaceresm@unal.edu.co (CHC-M). \\ ${ }^{3}$ Programa de Doctorado en Ciencias Biológicas, Mención Ecología, Laboratorio de Biología Evolutiva, Pontificia Universidad \\ Católica de Chile. Santiago, Chile. Email: aeacevedo@uc.cl (AAR). \\ ${ }^{4}$ Grupo de Mastozoología, Instituto de Biología, Universidad de Antioquía. Medellín, Colombia. Email: andresarias3@yahoo.es (AA-A). \\ ${ }^{5}$ Proyecto de Conservación de Aguas y Tierras, ProCAT Colombia/Internacional. Calle 97A \# 10-67, Of. 202. Bogotá, Colombia. \\ Email: jfgonzalezmaya@gmail.com (JFG-M). \\ ${ }^{6}$ Instituto de Ecología, Universidad Nacional Autónoma de México, Circuito Exterior s/n, Ciudad Universitaria, Ciudad de México, \\ México, México. \\ *Autor de correspondencia
}

Even though the puma (Puma concolor) is the second largest felid in America and is widely distributed in both the continent and in Colombia. Knowledge about its food habits in many areas of the Neotropics, especially in the highlands, is still limited. We surveyed nine localities in Tamá NNP (National Natural Park) and its buffer zone monthly from June 2012 to May 2015, between 2,067 and 3,500 masl. We surveyed three linear transects of 2 to $3 \mathrm{~km}$ in each locality searching for scats, which were located mainly on mountain ridges. We analyzed fecal contents and estimated the minimum number of samples needed to describe puma diet, as well as the absolute frequency of records for each prey species, their relative frequency of occurrence, and biomass consumed. Potential prey species were identified using photos from camera traps at the same localities. Fecal analysis ( $n=45$ ) suggests at least eight species of medium-sized mammals as prey. Of these, three species were the most frequent, contributing $67.87 \%$ of the biomass consumed: Nasua nasua, Mazama rufina and Cuniculus taczanowskii. The latter is a newly reported food item for the puma. No large or domestic species were recorded as part of the species' diet for the study area, in spite of its availability. Considering the potential conflict with communities surrounding the protected area, by the alleged consumption of farm animals by this and other felids, it appears that the availability of wild prey in Tamá NNP is suitable for puma and apparently the species does not need to use alternative prey as livestock. Our data suggest that the minimum number of samples required to estimate the diet in our study area varies between 31 and 41 , suggesting that our results ( $n=45$ ) are a good estimate of the species' diet. This work highlights the importance of expanding the knowledge about puma foraging ecology in order to generate better conservation strategies for a species of great importance for the dynamics and stability of the Colombian Andean ecosystems.

A pesar de que el puma (Puma concolor) es el segundo felino más grande en América y presenta una amplia distribución tanto en el continente como en Colombia. La información sobre los hábitos alimenticios en muchas de las áreas a nivel del Neotrópico, especialmente en zonas altas, aún es limitada. Se realizaron muestreos en nueve localidades del PNN (Parque Nacional Natural) Tamá y su zona de amortiguación mensualmente entre junio del 2012 y mayo del 2015, entre los 2,067 y 3,500 msnm. Se realizaron tres transectos lineales de entre 2 y 3 km (por cada localidad) para búsqueda de heces, las que se ubicaron principalmente sobre las crestas de las montañas. Se analizó el contenido y se estimó el número mínimo de muestras necesario para describir la dieta del Puma, la frecuencia absoluta de las presas, de ocurrencia y biomasa consumida. Las especies potenciales también se obtuvieron a través de cámaras trampa de las mismas localidades. El análisis de excretas $(n=45)$ indicó al menos ocho especies de mamíferos medianos como presas. Las tres más frecuentes y las que aportan en conjunto el $67.87 \%$ de la biomasa consumida son: Nasua nasua, Mazama rufina y Cuniculus taczanowskii. Esta última especie es un nuevo registro en la dieta para el puma. Ninguna especie grande o doméstica fue registrada como parte de la dieta para el área de estudio, a pesar de su disponibilidad. Aunque el conflicto potencial con comunidades aledañas al área protegida es el supuesto consumo de animales domésticos, parece que la disponibilidad de presas silvestres en el PNN Tamá es la adecuada para los pumas y no tienen necesidad de utilizar presas alternativas como el ganado. Nuestros datos muestran que el número mínimo de muestras necesarias para estimar la dieta del puma es de 31 a 41 , lo que sugiere que este trabajo ( $n=45$ ) es una buena aproximación. Este trabajo resalta la importancia de conocer aún más sobre estos aspectos ecológicos para así poder generar mejores estrategias de conservación para la especie, la cual es de gran importancia para la dinámica y estabilidad de los ecosistemas Andinos del país.

Keywords: Andes; biomass; dietary habits; puma.

() 2018 Asociación Mexicana de Mastozoología, www.mastozoologiamexicana.org

\section{Introduction}

The puma (Puma concolor) is the felid with the largest distribution in America, occupying areas from southern Canada to southern Chile and Argentina (Currier 1983). In this large range, the species inhabits a wide variety of habitats (i. e., savannas, humid forests, deserts) including some periurban landscapes surrounding large cities (Mazzolli 2012; Arias-Alzate et al. 2015). In the Neotropics the species is considered the main predator in mountain ecosystems, especially in areas above 2,000 masl (De Angelo et al. 2009, Arias-Alzate et al. 2015).

Despite its importance as a top predator in most ecosystems that it inhabits (e. g., regulates and maintain prey populations; Hoogesteijn and Hoogesteijn 2005, Hunter and Barrett 2011), most studies about puma diet come from high latitudes or Neotropical lowlands where diet 
has been reported as highly diverse and strongly dependent on mammals (Chinchilla 1997; Pessino et al. 2001; Moreno et al. 2006; Hernández 2008, Skewes et al. 2012). For instance, diet in North American populations is mostly composed of large ungulates (e. g., Odocoileus hemionus; Iriarte et al. 1990), while in Central America and southern South America the puma shows a tendency towards feeding on medium and small species (e. g., Dasyprocta spp., Cuniculus spp., Pecari tajacu and Mazama spp.; Currier 1983; Emmons 1987; Nuñez et al. 2000; Pessino et al. 2001; Polisar et al. 2003; Novack et al. 2005; Hernández 2008; Pontes and Chivers 2007). In contrast to the work done elsewhere, studies on puma diet in other regions of South America (e. g., northwest) are still scarce, especially in highlands, which have only recently received a little attention (HernándezGuzmán et al. 2011).

In Colombia, little is known about the foraging ecology of this species and most information comes from opportunistic unpublished records and personal communications with only one systematic study, from Puracé National Natural Park in the central range of the Colombian Andes (departments of Cauca and Huila; Hernández-Guzmán et al. 2011). Here we assess puma diet in the northern Andes, in the highlands of Tamá NNP (National Natural Park; department of Norte de Santander). We emphasize that this knowledge is of great significance, since it provides greater understanding of the species' ecology and its interactions with other species, information needed for the definition of better strategies for puma management and conservation, especially in a protected area surrounded by human activities.

\section{Materials and methods}

Study area. The study was conducted in Tamá NNP, in the southeastern portion of the department Norte de Santander, in the eastern Andean range of Colombia. The park is under jurisdiction of the Toledo and Herrán municipalities between 2,067 and 3,356 masl $\left(7^{\circ} 02^{\prime}\right.$ and $7^{\circ} 27^{\prime}$ $\mathrm{N} ;-72^{\circ} 02^{\prime}$ and $-72^{\circ} 28^{\prime} \mathrm{W}$; Figure 1 ; Cáceres-Martínez et al. 2016). The park covers approximately $480 \mathrm{~km}^{2}$ of the Tamá Massif on the limits with Venezuela; Tamá NNP is part of a bi-national border protected area with El Tamá National Park in Venezuela.

Selection of sampling sites. The puma is the second largest cat present in Tamá NNP with a strict carnivorous diet, after the jaguar (Panthera onca; Cáceres-Martínez et al. 2016), so there is a potential for confusing scats from these two species, mainly when there are not associated tracks or other signs that allow certain species identification. Therefore, to avoid scat misidentification, we conducted the study only at high elevations (2,067 to 3,500 masl) where the jaguar is usually absent (De la Torre et al. 2018); jaguar have been recorded in the park only in lowlands (between 350 and 800 masl; Cáceres-Martínez et al. 2016). In this altitudinal range we selected nine localities for field sampling: La Carpa, La Rochela (buffer zone), Orocué, Páramo of

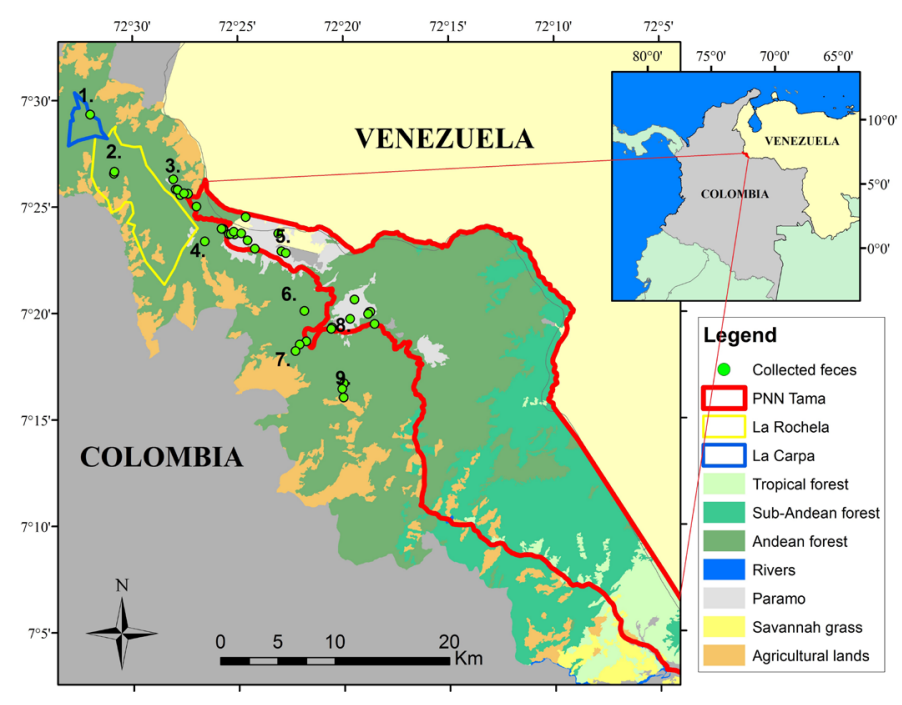

Figure 1. Cover types and locations of collected puma scats within Tamá National Natural Park and its buffer area in the high Andean region. 1. La Carpa. 2. La Rochela. 3. Orocué. 4. Páramo de la Cabrera. 5. Paramo of Tamá. 6. Belchite. 7. Asiria de Belén. 8. Páramo of Santa Isabel. 9. Santa Isabel.

Cabrera, Páramo of Tamá, Belchite, Asiria de Belén, Páramo of Santa Isabel, and Santa Isabel, covering a significant portion of the highlands of the park and buffer zone (Figure 1). Average temperature in these areas ranges from 6 to $16^{\circ} \mathrm{C}$ with precipitation variating between 800 and 2,000 mm/year with a frequent mist contributing to the constant humidity of the study area (Meneses et al. 2004).

Collection of scat samples. Scat collection was carried out from line-transects along trails, across natural covers following mountain ridges and on streambanks. At least three transects at each location, from 2 to $3 \mathrm{~km}$ in length, were sampled monthly between June 2012 and May 2015. Scats were identified as from puma by the presence of tracks and specific scat characteristics (i. e., diameter, length, presence of hairs), following the morphological description and biometrics of Aranda (2012). Scats were collected and stored in plastic bags for later analysis. For each sample we recorded geographical position, date and elevation.

Food habits and prey biomass analysis. To determine the puma's diet each scat was measured, weighed, and washed over wire mesh with tap water to separate the components (i. e., hair, bones, claws, and teeth). Afterwards, all samples were dried at room temperature for 48 hours (Ackerman et al. 1984). Each item was identified to species level using a reference collection of mammal specimens from the Instituto de Ciencias Naturales (ICN) collection at the National University of Colombia (Bogotá) and through literature review. All samples were deposited at the mammal collection of the Jose Celestino Mutis museum, Universidad of Pamplona. We also estimated the minimum number of scats required for an adequate diet description through a prey-species accumulation curve (Foster et al. 2010; Hernández-Guzmán et al. 2011). We performed this analysis by randomly adding all samples and estimating average and standard deviations from 1,000 permutations (Gotelli and Colwell 2001), thus eliminating the influence of the order in which each scat was added. The analysis was performed 
using Vegan Package v 2.4 - 2 with the function specaccum (Oksanen et al. 2007) implemented in R. We also estimated prey absolute frequency (AF) as the number of times a prey type was present in all scats collected (Rueda-Zozaya 2010) and then estimated the frequency of occurrence (FO) using the ratio of the absolute frequency $(\mathrm{AF})$ to the total number of scats (Rueda-Zozaya 2010). We then calculated the percentage of occurrence $(\mathrm{PO})$ as $(\mathrm{PO})=(\mathrm{AF}) /$ the total number of scats $\times 100$.

Biomass consumed (i. e., percentage of biomass) was calculated as the mean weight of each prey species multiplied by the frequency of each species, divided by the total weight of all species in the total scat samples, then multiplied by 100 (Medina et al. 2009). Body weights were based on literature reports (e. g., Ackerman et al. 1984; Eisenberg 1989; Ramírez 2011). As large-sized prey species are more likely to occur in smaller proportion in the scats than small species, due to differential ingestion and digestion, potentially leading to overestimation of some species (RuedaZozaya 2010), we applied a biomass correction factor using Ackerman's (1984) equation $(Y=1.98+0.035 X)$, where $Y$ is the weight of prey consumed per scat and $X$ is the mean weight of the prey species. Prey species identified in scats were corroborated with camera-traps records obtained in the same localities (Cáceres-Martínez et al. 2016).

\section{Results}

We collected a total of 45 scat samples (Appendix 1 ). The accumulation curve approached the asymptote, indicating that most potential prey species were detected within approximately 40 scat samples (Figure 2 ).

We identified eight prey species from the scats; other vertebrate items were found but their species identification was uncertain (Appendix 1) so they were excluded from analysis. The most commonly represented species were the South American coati (Nasua nasua), followed by the dwarf red brocket deer (Mazama rufina) and mountain paca (Cuniculus taczanowskii) with AF values of 9,6 and 5 respectively (Table 1 ). Meanwhile, the western mountain coati (Nasuella olivacea), the Central American agouti (Dasyprocta punctata), the nine-banded armadillo (Dasypus novemcinctus) and the two-toed sloth (Choloepus hoff-

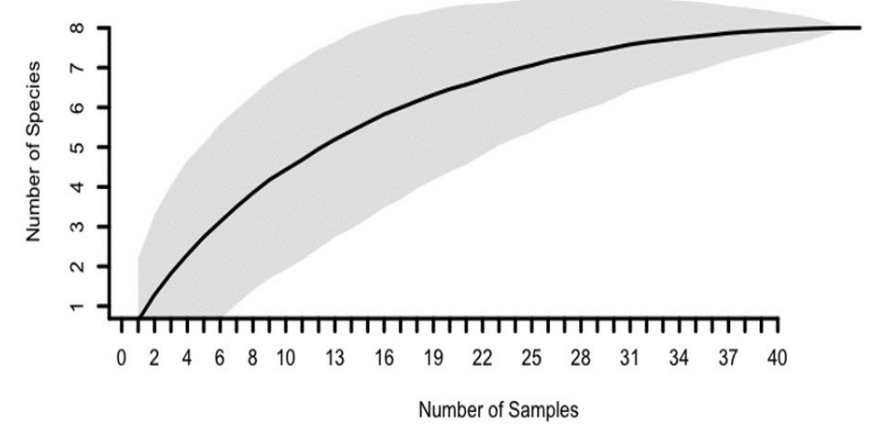

Figure 2. Prey species accumulation curves indicating the number of scats samples required to describe the food habits of puma in the study area; gray shading indicates $95 \%$ confidence interval. manni) were less frequently detected (Table 1 ). The species with the largest FO and PO was N. nasua followed by $M$. rufina (Table 1).

In terms of biomass consumed, C. taczanowskii presented the greatest contribution per individual $(2.435 \mathrm{~kg}$; Table 1); however, N. nasua contributed more to the total biomass consumed ( $28.6 \%$ of biomass consumed), followed by M. rufina (20.71\%) and C. taczanowskii (18.54 $\%)$, together accounting for $67.87 \%$ of the total biomass. The other five species contributed together the remaining $32.13 \%$ of the total biomass consumed by puma (Table 1 ). No large or domestic species were recorded as consumed by puma in the study area.

Table 1. Composition of puma's diet and relative biomass consumed based on 45 scats collected in Tamá NNP: Absolute frequency (AF), frequency of occurrence (FO), percentage of occurrence (PO), mean prey weight (MPW), biomass correction factor (BCF) and relative biomass consumed (RBC).

\begin{tabular}{lrrrrrrr}
\hline Species prey & FA & FO & $\begin{array}{l}\text { PO } \\
\text { (\%) }\end{array}$ & $\begin{array}{l}\text { MPW } \\
(\mathbf{k g})\end{array}$ & $\begin{array}{l}\text { BCF } \\
(\mathbf{k g})\end{array}$ & $\begin{array}{l}\text { RBC } \\
(\mathbf{k g})\end{array}$ & $\begin{array}{l}\text { Biomass } \\
(\%)\end{array}$ \\
\hline Nasua nasua & 9 & 0.20 & 20.00 & 3.07 & 2.08 & 18.79 & 28.61 \\
Mazama rufina & 6 & 0.13 & 13.33 & 8.20 & 2.26 & 13.60 & 20.72 \\
Cuniculus taczanowskii & 5 & 0.11 & 11.00 & 13.00 & 2.43 & 12.18 & 18.54 \\
Nasuella olivacea & 3 & 0.06 & 6.00 & 1.50 & 2.03 & 6.10 & 9.29 \\
Choloepus hoffmanni & 2 & 0.04 & 4.40 & 5.70 & 2.18 & 4.36 & 6.64 \\
Didelphis marsupialis & 2 & 0.04 & 4.40 & 5.50 & 2.17 & 4.35 & 6.62 \\
Dasypus novemcinctus & 2 & 0.04 & 4.40 & 3.10 & 2.08 & 4.18 & 6.36 \\
Dasyprocta punctata & 1 & 0.02 & 2.20 & 4.00 & 2.12 & 2.12 & 3.23 \\
\hline
\end{tabular}

\section{Discussion}

Our work represents the first study on $P$. concolor conducted in northeastern Colombia and the second study in a protected area of the Colombian Andes. The minimum number of scats necessary to assess puma diet could vary depending on the conditions of each location, which would require different sampling efforts according to particular temporal and spatial contexts. Our data showed that the minimum number of scats necessary for estimating the species' diet in our study area is between 31 and 41 scats, suggesting that our sampling $(n=45)$ was adequate to give an accurate estimate of the species' diet. This result corresponds with previous studies in Mexico by Monroy-Vilchis et al. (2009) and Núñez et al. (2000) which suggested a minimum of 15 and 40 scats, respectively; in Colombia, a study in Puracé NNP in the Central Andes of Colombia estimated a minimum requisite of 20 scats (Hernández-Guzmán et al. 2011), which overlaps our estimation.

Even though it appears we had a sufficient sampling effort, it is likely some prey species were not detected given our method based on comparisons with reference material (Klare et al. 2011). For instance, $50 \%$ of the samples had unidentified items due to the advanced state of decomposition. To avoid this loss of information, Foster et al. (2010) suggested from species accumulation curves that the minimum sample size required to fully characterize the species' diet should include at least 100 scats; however, high decomposition rates associated with warm and/or humid 

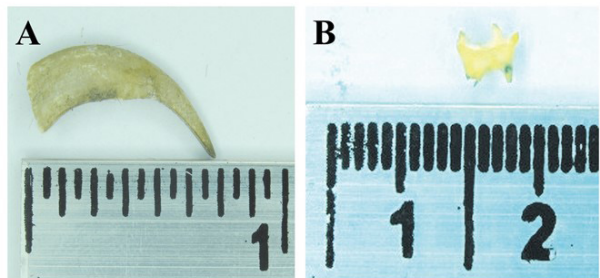

C

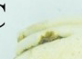

D

E

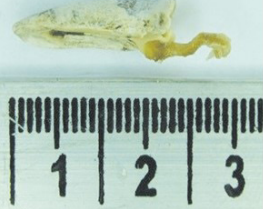

G
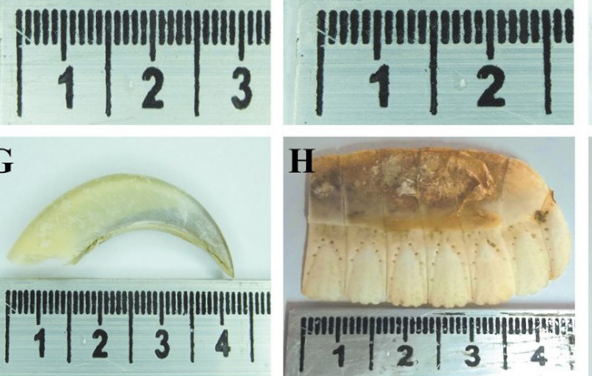

Figure 3. Prey species recorded in puma scat in Tamá NNP a) Nasua nasua, b) Didelphis marsupialis, c) Cuniculus taczanowskii, d) Dasyprocta punctata, e) Nasuella olivacea, f) Mazama rufina, g) Choloepus hoffmanni, h) and i). Dasypus novemcinctus.

conditions, such as those in tropical and cloud forests, may limit the availability and processing of scats.

Our results showed that the most frequently consumed prey species in the study area are small- to medium-sized mammals. Prey species composition in our results were very similar to those reported in other studies along different areas of the Neotropics (Nuñez et al. 2000, Crawshaw and Quigley 2002, Novack et al. 2005, Moreno et al. 2006, De Azevedo 2008, Foster et al. 2010). However, frequency of species occurrence varies considerably across studies. We found that for Tamá NNP, N. nasua, M. rufina, and C. taczanowskii (followed by $N$. olivacea) were the most frequently consumed species by puma, which is very similar to previous studies in Central and South America. For instance, numerous studies have found Nasua spp. among the most frequent prey in puma's diet in México (Nuñez et al. 2000), Belize (Foster et al. 2010), Guatemala (Novack et al. 2005), Costa Rica (Chinchilla 1997), and Brazil (De Azevedo 2008); Mazama spp. have also been among the most frequently reported prey from Belize (Foster et al. 2010), Guatemala (Novack et al. 2005), Costa Rica (Chinchilla 1997) and Brazil (Crawshaw and Quigley 2002, De Azevedo 2008). As in our study, other studies have frequently identified mediumsized rodents (Dasyprocta spp. and Cuniculus spp.) species in the diet, with examples from Panama (Moreno et al. 2006), Bolivia (Pacheco 2004), and Brazil (De Azevedo 2008). Overall, with slight taxonomic differences and some frequency variation, puma's diet in our study followed patterns similar to that in other regions and ecosystems in the Neotropics.

We found very similar results to those from the only other study on puma's diet in Colombia (Puracé NNP; HernándezGuzmán et al. 2011), likely because of the highly similar ecosystems sampled. In Puracé NNP the most frequent prey species found were northern pudú (Pudu mephistophiles), N. olivacea, and Mazama sp. (likely M. rufina). Differences in species composition may reflect that Northern Pudú is not present in the Eastern Andean range of Colombia (Barrio and Tirira 2008) and N. nasua is not abundant above 3,000 masl (González-Maya et al. 2015); however, Mazama sp. was also among the most frequent prey species in Puracé NNP, and the largest contribution to biomass consumed was also N. olivacea and Mazama sp. as in our results. Previous published studies from the high Andes are scarce, so the record of C. taczanowskii can be considered as the first record of this species in the puma's diet across its distribution.

It is important to note that the consumption of Coendou rufescens by puma has been previously reported in the páramo of Belmira (2,800 to 3,000 masl, Antioquia department, north of the Central Andean range; Arias-Alzate pers. obs.); although this species is not found in Tamá NNP and it was not found on the scats collected; a similar species occurs in the area (i. e., Coendou pruinosus), so it could be expected in the diet. Chinchilla (1997) also highlighted a frequent consumption of Coendou mexicanus in the lowlands of Corcovado National Park, Costa Rica. Other potential prey species that were expected to be part of the puma's diet in Tamá NNP, and that were previously recorded by camera traps, included Didelphis pernigra, Sciurus granatensis, Conepatus semistriatus, and Mustela frenata (CáceresMartínez et al. 2016). However, and despite they have been reported previously in the diet, we did not find them in the scats collected.

It seems that variations in puma's diet are the result of opportunistic predation by this species, adapting its feeding behavior according to prey species availability both at the latitudinal and the altitudinal levels (Iriarte et al. 1990). Moreover, at high elevations or in regions sympatric with jaguars, pumas tend to prey more frequently on mediumsized species such as agoutis (Dasyprocta spp.), pacas ( $C$. paca and C. taczanowskii), coatis (N. narica, N. olivacea and N. nasua), and deer (P. mephistophiles, Mazama gouazoubira and $M$. rufina) and apparently only prey on large mammals and other small species to supplement their diet (Nuñez et al. 2000, Novack et al. 2005, De Azevedo 2008, HernándezGuzmán et al. 2011). However, the preferred prey size may also be limited by environmental conditions; for instance, puma typically prey more frequently on large species (frequently deer) in temperate zones (Dalrymple and Bass 1996, Cunningham et al. 1999, Moreno et al. 2006).

For some carnivore species, such as large felids (e. $g$. puma and jaguar), the lack of suitable habitats and prey species as a consequence of anthropic pressure (e.g., deforestation and hunting) may promote predation on livestock (Hoogesteijn and Hoogesteijn 2005, De Azevedo 2008). It seems that both habitat availability and the prey base at Tamá NNP are likely sufficient to avoid such behaviors, given that no livestock or other domestic species were found on the scats; pumas in Tamá may have no need to use such alternative prey. In other regions of Colombia 
(e. g., Antioquia), generally considered more impacted by humans, puma consumption of livestock has been frequently recorded (Arias-Alzate et al. 2013, González-Maya et al. 2013), indicating that conflict prevention, and the conservation of puma, depends on the maintenance of healthy ecosystems and local prey base via sustainable forest management and poaching control.

Our results represent significant knowledge of what is likely the most important Andean predator and they provide the baseline for understanding patterns of assemblage dynamics and thus for informing conservation. Changes in puma diet dynamics will likely reflect in changes in the composition and structure of mammal assemblages, not only represented as part of puma ecology, but also in general ecosystem dynamics and function. Our data can provide the base to understand the potential responses of species assemblages to changes in threats, both inside protected areas and surrounding areas, all increasingly dominated by human activities.

We highlight the importance of continuing long-term monitoring of these ecological processes, and in general with the generation of this type of studies in other regions of Colombia, to support better conservation strategies for species such as the puma, given the important roles it plays in ecosystem dynamics and stability in both protected and unprotected areas.

\section{Acknowledgments}

This work was developed thanks to research permit No. 132 from July 26 to December 11 of 2013, and Resolution No. 114 from August 13 of 2015, provided by Parques Nacionales Naturales de Colombia. We also acknowledge support from the Instituto de Ciencias Naturales (Universidad Nacional de Colombia), ProCAT Colombia, the A. A. Escobar Foundation (FAAE), WCS-Colombia, Parques Nacionales Naturales de Colombia, and Parque Nacional Natural Tamá. We especially thank our field assistants and Tamá park rangers for their help and contribution during fieldwork. Academic and Research Vice-rectories from Universidad de Pamplona and Idea Wild provided financial and logistical support. We thank L. Sánchez- González, R. Van Horn and two anonymous reviewers for comments that significantly improved this manuscript.

\section{Literature cited}

Ackerman, B., F. Lindzey, and T. Hemker. 1984. Cougar food habits in southern Utah. Journal Wildlife Manage 48:147-155.

Aranda, M. 2012. Huellas y otros rastros de los mamíferos grandes y medianos de México. Instituto de Ecología, A. C. Xalapa, México.

Arias-Alzate A., S. Botero-Cañola, J. D. Sánchez-Londoño and S. Solari. 2013. Presencia de felinos y evidencias de conflicto con humanos en tres regiones de Antioquia. Pp. 145-154, in Grandes felinos de Colombia (Payán Garrido, E., and C. Castaño-Uribe, eds.). Panthera Colombia, Fundación Herencia Ambiental Caribe, Conservación
Internacional and Cat Specialist Group UICN/SSC. Bogotá, Colombia.

Arias-Alzate, A., C. A. Delgado-V, J. F. Navarro, and J. F. GonzálezMAYA. 2015. Presencia de Puma (Puma concolor) en un paisaje periurbano al sur del Valle de Aburrá, Antioquia, Colombia. Mammalogy Notes 2:24-28.

BarRIO, J., AND D. TIRIRA. 2008. Pudu mephistophiles. The IUCN Red List of Threatened Species.. Version 2017.3. www.iucnredlist. org. Downloaded on 30 April 2018.

Cáceres-Martínez, C. H., A. A. Acevedo-Rincón, and J. González-Maya. 2016. Terrestrial medium and large-sized mammal's diversity and activity patterns from Tamá National Natural Park and buffer zone, Colombia. Therya 7:285-298.

Chinchilla, F. A. 1997. La dieta del jaguar (Panthera onca), el puma (Felis concolor) y el manigordo (Felis pardalis) (Carnívora: Felidae) en el Parque Nacional Corcovado, Costa Rica. Revista de Biología Tropical 45:1223-1229.

Crawshaw, P. G., and H. B. Quigley. 2002. Hábitos alimentarios del jaguar y el puma en el Pantanal, Brasil, con implicaciones para su manejo y conservación. Pp. 223-235 in El Jaguar en el Nuevo Milenio (Medellín, R. A., C. Equihua, C. L. Chetkiewicz, P. G. Crawshaw Jr., A. Rabinowitz, K. H. Redford, J.G. Robinson, E. W. Sanderson, and A. B. Taber, eds.). Universidad Nacional Autónoma de México, Wildlife Conservation Society y Fondo de Cultura Económica. Ciudad de México, México.

Cunningham, S. C., C. R. Gustavson, and W. B. Ballard. 1999. Diet selection of mountain lions in southeastern Arizona. Journal of Range Management 52:202-207.

CurRIER, M. J. P. 1983. Felis concolor. Mammalian Species 1:1-7.

DalRYMPLE, G. H., AND O. L. JR. BAsS. 1996. The diet of the Florida panther in Everglades National Park, Florida. Bulletin Florida Museum of Natural History 39:173-193.

De Angelo, C. 2009. El paisaje del Bosque Atlántico del Alto Paraná y sus efectos sobre la distribución y estructura poblacional del jaguar (Panthera onca) y el puma (Puma concolor). Mastozoología Neotropical 16:507-508.

De Azevedo, F. C. C. 2008. Food habits and livestock depredation of sympatric jaguars and pumas in the Iguaçu National Park Area, South Brazil. Biotropica 40:494-500.

De la Torre J. A., J. F. González-Maya, H. Zarza, G. Ceballos, and R. MedelLín. 2018. The jaguar's spots are darker than they appear: assessing the global conservation status of the jaguar Panthera onca. Oryx 52:300-315.

EISENBERG, J. F. 1989. Mammals of the Neotropics of Panamá, Colombia, Venezuela, Guayana, Surinam, Guayana Fancesa. The University of Chicago Press. Chicago, U. S. A.

Emmons, L. H. 1987. Comparative feeding ecology of felids in a neotropical rainforest. Behavioral ecology and sociobiology 20:271-283.

Foster, R. J., B. J. Harmsen, B. Valdes, C. Pomilla, and C. P. Doncaster. 2010. Food habits of sympatric jaguars and pumas across a gradient of human disturbance. Journal of Zoology 280:309-318.

González-Maya J. F., J. Racero-Casarrubia, and A. Arias-Alzate. 2013. Records of occasional puma hunting for consumption in Colombia. CatNews 58:9-10.

GonzÁlez-Maya, J.F., I.M. Vela-Vargas, J.S. Jiménez-Alvarado, A.P. Hurtado-Moreno, C. Moreno, I. Aconcha-Abril, and D.A. ZÁRRATE-ChARRY. 2015. First sympatric records of Coatis 
(Nasuella olivacea and Nasua nasua; Carnivora: Procyonidae) from Colombia. Small Carnivore Conservation 52 \& 53:93-100.

Gotelli, N. J., ANd R. K. Colwell. 2001. Quantifying biodiversity: procedures and pitfalls in the measurement and comparison of species richness. Ecology Letters 4:379-391.

Hernández G. C. 2008. Dieta, uso de hábitat y patrones de actividad del puma (Puma concolor) y el jaguar (Panthera onca) en la selva Maya. Revista Mexicana de Mastozoología 12:113-130.

Hernández-Guzmán A., E. Payán, and O. Monroy-Vilchis. 2011. Hábitos alimentarios del Puma concolor (Carnivora: Felidae) en el Parque Nacional Natural Puracé, Colombia. Revista de Biología Tropical 59:1285-1294.

Hoogesteijn, R., AND A. Hoogesteijn. 2005. Manual sobre problemas de depredación causados por grandes felinos en hatos ganaderos. Wildlife Conservation Society. Campo Grande, Brazil.

Hunter, L., And P. Barrett. 2011. Carnivores of the world. Princeton University Press. New Jersey, U. S. A.

Iriarte, A., W. Franklin, W. Johnson, and K. Redford. 1990. Biogeographic variation of foods habits and body size of the America puma. Oecología 85:185-190

Klare U., F. Kamler Jan, and D. Macdonald. 2011. A comparison and critique of different scat-analysis methods for determining carnivore diet. Mammal Review 41:294-312.

MAzzolul, M. 2012. Natural recolonization and suburban presence of pumas (Puma concolor) in Brazil. Journal Ecology and Natural Environment 4:344-362.

Medina, C., C. Díaz, F. Delgado, G. Ynga, and H. Zela. 2009. Dieta de Conepatus chinga (Carnívora: Mephitidae) en un bosque de Polylepis del departamento de Arequipa, Perú. Revista Peruana de Biología 16:183-186.

Meneses L., J. Jiménez, A. Romero, C. Leal, D. Castillo, E. Heredia, F. Perez, I. Uribe, J. Contreras, and W. Toncel. 2004. Plan de manejo Parque Nacional Natural Tamá. Dirección Territorial Andes Nororientales Parques Nacionales Naturales de Colombia. Toledo, Colombia.

Monroy-Vilchis, O., Y. Gomez, M. JancZUR, And V. URIOS. 2009. Food niche of Puma concolor in central Mexico. Wildlife Biology 15:97-105.

Moreno, R. S., R. W. Kays, and R. Samudio. 2006. Competitive release in diets of ocelot (Leopardus pardalis) and puma (Puma concolor) after jaguar (Panthera onca) decline. Journal of Mammalogy 87:808-816.

NovaCk, A. J., M. B. Main, M. E. Sunguist, AND R.F. LabISky. 2005. Foraging ecology of jaguar (Panthera onca) and puma (Puma concolor) in hunted and non-hunted sites within the Maya Biosphere Reserve, Guatemala. Journal of Zoology 267:167-178.

NúÑez, R., B. Miller, AND F. LindZey. 2000. Food habits of jaguars and pumas in Jalisco, Mexico. Journal of Zoology 252:373-379.

Oksanen, J., R. Kindt, P. Legendre, B. O'hara, M. H. H. Stevens, M. OKSANEN, AND M. A. Suggests. 2007. Vegan: Community ecology package 10:631-637.

Pacheco, L. F., A. Lucero, and M. Villca. 2004. Dieta del puma (Puma concolor) en el Parque Nacional Sajama, Bolivia y su conflicto con la ganadería. Ecología en Bolivia 39:75-83.

Pessino, M. E., J. Sarasola, C. Wander, and N. Besoky. 2001. Respuesta a largo plazo del puma (Puma concolor) a una declinación poblacional de la vizcacha (Lagostomus maximus) en el desierto del Monte, Argentina. Ecología austral 11:61-67.

Polisar J., I. Maxit, D. Scognamillob, L. Farrell, E. Melvin, M. E. Sunquist, AND J. F. EISENBERG. 2003. Jaguars, pumas, their prey base and cattle ranching: Ecological interpretations of a management problem. Biological Conservation 109:297-310.

Pontes A. R., and D. J. Chivers. 2007. Peccary movements as determinants of the movements of larges cats in Brazilian Amazonia. Journal of Zoology 273:257-265.

Ramirez S. M. 2011. Observaciones de forrajeo y defensa de Nasuella olivacea (Carnívora: Procyonidae) en el Volcán Pasochoa, Pichincha-Ecuador. Boletín técnico 10, serie zoológica 7:47-50.

Rueda-ZozayA, R. 2010. Determinación de la dieta del Jaguar (Panthera onca) y Puma (Puma concolor) en el municipio de Tamasopo. San Luis Potosí, México.

Skewes O., C. Moraga, A. Arriagada, and J. R. Rau. 2012. El jabalí europeo (Sus scrofa): Un invasor biológico como presa reciente del puma (Puma concolor) en el sur de Chile. Revista Chilena de Historia Natural 85:227-232.

Associated editor: Mariana Freitas Nery

Submitted: January 18, 2017; Reviewed: April 27, 2018;

Accepted: July 6, 2018; Published on line: August 2, 2018. 


\section{Appendix 1}

Appedix1. Species consumed by puma (Puma concolor) in Tamá National Natural Park Andean based on remnants of prey in scats ( $n=45$ ).

\begin{tabular}{|c|c|c|c|c|c|c|c|c|c|}
\hline ID & N. nasua & C. taczanowskii & N. olivacea & D. marsupialis & D. punctata & M. rufina & C. hoffmanni & D. novemcinctus & Vertebrate \\
\hline 1 & $x$ & $x$ & - & - & - & - & - & - & $x$ \\
\hline 2 & $x$ & - & - & - & - & - & - & - & $x$ \\
\hline 3 & - & - & - & - & - & - & - & - & - \\
\hline 4 & - & - & $x$ & $x$ & - & - & - & - & $x$ \\
\hline 5 & - & - & - & - & - & - & - & - & - \\
\hline 6 & - & - & - & - & - & $x$ & - & - & $x$ \\
\hline 7 & - & - & - & - & $x$ & - & - & - & $x$ \\
\hline 8 & - & - & - & - & - & $x$ & - & - & $x$ \\
\hline 9 & - & $x$ & - & - & - & - & - & - & $x$ \\
\hline 10 & $x$ & $x$ & $x$ & - & - & - & - & - & $x$ \\
\hline 11 & - & - & $x$ & - & - & - & - & - & $x$ \\
\hline 12 & - & - & - & - & - & - & - & - & - \\
\hline 13 & $x$ & - & - & - & - & - & - & - & $x$ \\
\hline 14 & - & - & - & $x$ & - & - & - & - & $x$ \\
\hline 15 & - & - & - & - & - & - & $x$ & - & $x$ \\
\hline 16 & - & - & - & - & - & - & - & - & - \\
\hline 17 & $x$ & - & - & - & - & - & - & - & $x$ \\
\hline 18 & $x$ & - & - & - & - & - & - & - & $x$ \\
\hline 19 & - & $x$ & - & - & - & - & - & - & $x$ \\
\hline 20 & - & - & - & - & - & - & - & - & - \\
\hline 21 & - & - & - & - & - & - & - & - & - \\
\hline 22 & - & - & - & - & - & - & - & - & - \\
\hline 23 & - & - & - & - & - & - & - & - & - \\
\hline 24 & $x$ & - & - & - & - & - & - & - & $x$ \\
\hline 25 & - & - & - & - & - & - & - & - & - \\
\hline 26 & - & - & - & - & - & - & - & - & - \\
\hline 27 & - & - & - & - & - & - & - & - & - \\
\hline 28 & - & - & - & - & - & - & - & - & - \\
\hline 29 & - & - & - & - & - & - & - & - & - \\
\hline 30 & - & - & - & - & - & $x$ & - & - & $x$ \\
\hline 31 & - & - & - & - & - & - & - & - & - \\
\hline 32 & - & - & - & - & - & - & - & - & - \\
\hline 33 & - & - & - & - & - & - & - & - & - \\
\hline 34 & - & - & - & - & - & - & - & - & - \\
\hline 35 & - & - & - & - & - & - & - & - & - \\
\hline 36 & $x$ & - & - & - & - & $x$ & - & - & $x$ \\
\hline 37 & - & - & - & - & - & - & - & - & - \\
\hline 38 & $x$ & - & - & - & - & $x$ & - & - & $x$ \\
\hline 39 & - & - & - & - & - & - & - & $x$ & $x$ \\
\hline 40 & - & - & - & - & - & - & - & - & - \\
\hline 41 & - & $x$ & - & - & - & - & - & - & $x$ \\
\hline 42 & - & - & - & - & - & - & - & - & - \\
\hline 43 & - & - & - & - & - & - & $x$ & - & $x$ \\
\hline 44 & - & - & - & - & - & $x$ & - & $x$ & $x$ \\
\hline 45 & - & - & - & - & - & - & - & - & - \\
\hline
\end{tabular}




\begin{tabular}{|c|c|c|c|c|c|c|c|c|c|}
\hline ID & N. nasua & C. taczanowskii & $N$. olivacea & D. marsupialis & D. punctata & M. rufina & C. hoffmanni & D. novemcinctus & Vertebrate \\
\hline 1 & $\mathrm{x}$ & $\mathrm{x}$ & - & - & - & - & - & - & $\mathrm{x}$ \\
\hline 2 & $x$ & - & - & - & - & - & - & - & $x$ \\
\hline 3 & - & - & - & - & - & - & - & - & - \\
\hline 4 & - & - & $x$ & $x$ & - & - & - & - & $x$ \\
\hline 5 & - & - & - & - & - & - & - & - & - \\
\hline 6 & - & - & - & - & - & $x$ & - & - & $\mathrm{x}$ \\
\hline 7 & - & - & - & - & $x$ & - & - & - & $x$ \\
\hline 8 & - & - & - & - & - & $x$ & - & - & $x$ \\
\hline 9 & - & $x$ & & & - & & & & $x$ \\
\hline 10 & $\mathrm{x}$ & $\mathrm{x}$ & $x$ & - & - & - & - & - & $\mathrm{x}$ \\
\hline 11 & - & - & $x$ & - & - & - & - & - & $x$ \\
\hline 12 & - & - & - & - & - & - & - & - & - \\
\hline 13 & $x$ & - & - & - & - & - & - & - & $x$ \\
\hline 14 & - & - & - & $x$ & - & - & - & - & $x$ \\
\hline 15 & - & - & - & - & - & - & $x$ & - & $x$ \\
\hline 16 & - & - & - & - & - & - & - & - & - \\
\hline 17 & $x$ & - & & & - & & & & $x$ \\
\hline 18 & $x$ & - & - & - & - & - & - & - & $x$ \\
\hline 19 & - & $\mathrm{x}$ & - & - & - & - & - & - & $x$ \\
\hline 20 & - & - & - & - & - & - & - & - & - \\
\hline 21 & - & - & - & - & - & - & - & - & - \\
\hline 22 & - & - & - & - & - & - & - & - & - \\
\hline 23 & - & - & - & - & - & - & - & - & - \\
\hline 24 & $x$ & - & - & - & - & - & - & - & $x$ \\
\hline 25 & - & - & - & - & - & & & - & - \\
\hline 26 & - & - & - & - & - & - & - & - & - \\
\hline 27 & - & - & - & - & - & - & - & - & - \\
\hline 28 & - & - & - & - & - & - & - & - & - \\
\hline 29 & - & - & - & - & - & - & - & - & - \\
\hline 30 & - & - & - & - & - & $x$ & - & - & $x$ \\
\hline 31 & - & - & - & - & - & & & - & \\
\hline 32 & - & - & - & - & - & - & - & - & - \\
\hline 33 & - & - & - & - & - & - & - & - & - \\
\hline 34 & - & - & - & - & - & - & - & - & - \\
\hline 35 & - & - & - & - & - & - & - & - & - \\
\hline 36 & $x$ & - & & - & - & $x$ & & - & $x$ \\
\hline 37 & - & - & - & - & - & - & - & - & - \\
\hline 38 & $x$ & - & - & - & - & $x$ & - & - & $x$ \\
\hline 39 & - & - & - & - & - & & & $x$ & $x$ \\
\hline 40 & - & - & - & - & - & - & - & - & - \\
\hline 41 & - & $x$ & - & - & - & - & - & - & $x$ \\
\hline 42 & - & - & - & - & - & - & - & - & - \\
\hline 43 & - & - & - & - & - & - & $x$ & - & $x$ \\
\hline 44 & - & - & - & - & - & $x$ & - & $x$ & $x$ \\
\hline 45 & - & - & - & - & - & & & & \\
\hline TOTAL & 9 & 5 & 3 & 2 & 1 & 6 & 2 & 2 & 23 \\
\hline
\end{tabular}

